\title{
The Development Strategy of Green Assets Securitization under the Rural Revitalization Strategy
}

\author{
Jingjing Sun* \\ School of Finance \\ Guizhou University of Finance and Economics \\ Guiyang, China \\ 2993020919@qq.com
}

\author{
Li Shi \\ School of Finance \\ Guizhou University of Finance and Economics \\ Guiyang, China
}

\begin{abstract}
According to the report of the 19th National Congress of the Communist Party of China, we should implement the strategy of rural revitalization and build a new type of village with prosperous industry, pleasant living environments, civilized countryside, effective governance and prosperity. To implement the strategy of rural revitalization, addressing the issues concerning agriculture, rural areas, and rural people should have a central place on the work agenda of the Party. And to solve these issues, we must first solve the problem of financing difficulties. Green asset securitization, with its own advantages, can effectively solve the problem of funds and provide funds for the construction of new villages. From the perspective of rural revitalization, this paper first defines the concept of green asset securitization, reviews the development of domestic green asset securitization in recent years, and then summarizes the problems faced by the development of green asset securitization. Finally, some suggestions from the aspects of relevant laws, professionals and market supervision are put forward to promote the development of green asset securitization.
\end{abstract}

Keywords-green asset securitization; rural revitalization; green credit; basic assets

\section{INTRODUCTION}

With "green" becoming one of the mainstream development concepts in China, the 19th National Congress of the CPC explicitly proposed "accelerating the reform of the ecological civilization system and building a beautiful China". In July 2018, the Eco Forum Global Guiyang was held, and Vice Minister of Ecological Environment Huang Runqiu proposed to form a GDP + GEP assessment mechanism, requiring simultaneous economic and ecological development. Green finance plays an increasingly prominent role in implementing the concept of green development and promoting the construction of ecological civilization system. As a part of green finance, green asset securitization effectively broadens the financing channels of green industry with its own advantages, reduces the financing cost and promotes the sustainable development of green economy industry. The report of the 19th National Congress of the Communist Party of China put forward the " strategy of rural revitalization" to build a new type of village with prosperous industry, pleasant living environments, civilized countryside, effective governance and prosperity. The implementation of the rural revitalization strategy must first solve the problem of financing difficulties. Green asset securitization, as an innovative direct financing method developed rapidly in recent years, is superior to credit financing and has made some breakthroughs in financing scale and duration. Green asset securitization can be combined with the strategy of rural revitalization, using the cash flow generated by rural green projects as repayment support and raising funds to support the construction of new villages.

\section{Overview of GreEn Asset SeCuritization}

As an important part of the green financial system, green asset securitization has seen a rapid increase in circulation in the past two years under the encouragement of policies. Green Asset Securitization, that is, the cash flow of basic assets comes from the green industry or that raise funds to invest in the development of the green industry[1]. Green asset securitization can be divided into the following two categories: the first is direct green asset securitization, with green industry as the basic asset and the proceeds from issuing bonds invested in the green industry, and the second is indirect green asset securitization, in which corporate loans and green consumption loans for green industry projects are re-invested in the green industry.

Green asset securitization is the same as general asset securitization in terms of transaction structure, cash flow collection and credit enhancement, but it differs from other asset securitization in that, on the one hand, raised funds must be invested in green assets or projects; On the other hand, green asset securitization has a stricter information disclosure mechanism, which will help the society to supervise the use of funds. Therefore, this financing method will help improve the accuracy of the use of funds and the effectiveness of investment in green industries.

At the same time, green asset securitization has four characteristics:

First, the financing channels are wide. Credit financing limits are more difficult to finance, while emerging industries and green industries are more easily recognized by the capital market. Green industry has a large investment scale and a long investment period. Securitization can effectively broaden the 
financing channels and enable investors to flexibly decide the investment scale so as to obtain higher market recognition.

Second, investment accuracy has improved. Green asset securitization has stricter information disclosure requirements, so financing through asset securitization is more conducive to social supervision and can ensure that funds are invested in green projects, thus improving the effectiveness and accuracy of financing[2].

Third, the financing cost is low and the financing threshold is low. For small and medium-sized enterprises, high financing cost and high financing threshold have become important problems restricting their development. Enterprise development often depends on its own financing ability. Green asset securitization takes low-carbon environmental protection and energy-saving resource projects as its basic assets for securitization financing. The credit rating standard will be determined by the risk of green projects and will not be affected by the original issuer's own situation. Small and medium-sized enterprises can obtain the required financial support at low cost and low threshold.

Fourth, it has the function of "out - of - gauge and down lever". Assets traded in asset securitization and securities issued may not be reflected in the financial statements of enterprises, that is, they may be "listed". This way of handling can optimize corporate statements, reduce leverage ratio and improve return on assets.

\section{CURRENT SituAtion OF GREen AsSET SECURITIZATION IN CHINA}

\section{A. Green Asset Securitization Related Policies}

In March 2016, the Shanghai Stock Exchange began preparations for the establishment of a green corporate bond pilot, which includes green asset securitization. In May 2016, China Securities Regulatory Commission issued Questions and Answers on Supervision of Asset Securitization to explicitly support financing of green environmental protection industry projects by means of asset securitization[3]. On March 2, 2017, the CSRC issued China Securities Regulatory Commission's Guidance on Supporting the Development of Green Bond, defining the scope of green corporate bonds and green industry projects, encouraging market participants to invest in green corporate bonds, and specifying that the issuance of green asset-backed securities can be carried out according to the relevant requirements of green corporate bonds. In June, the bank and the CIRC also issued the Green Credit Statistics System, which clearly defined the statistical standards of green credit, including clean energy, renewable energy, green construction and other fields, thus standardizing the criteria for identifying green credit asset securitization. In April 2018, Shanghai Stock Exchange issued Vision and Action Plan of Shanghai Stock Exchange to Serve Green Development and Promote Green Finance (2018 - 2020), proposing to accelerate the development of green asset securitization, broaden the scope of basic assets, encourage enterprises to raise and issue green asset securitization and support green PPP project asset securitization.

\section{B. Issuance of Green Asset Securitization Market}

The first green credit asset-backed securities issued by Industrial Bank in 2014 raised nearly 3.5 billion yuan. Since 2015, the China Securities Regulatory Commission has carried out in-depth research on the development mechanism of green finance and vigorously innovated. There are five green asset securitization products listed on the Shenzhen Stock Exchange, accounting for about $10 \%$ of all financing projects.

In 2016, green asset securitization products made breakthroughs and innovations. In the inter-bank market, on January 5, the first green credit asset securitization product of this year was successfully issued in Industrial Bank, with a total issue amount of 2,645.7 million yuan. On the exchange market, on March 18, China's first ABS product of photovoltaic industry, "BOC Securities - Shenzhen Energy Nanjing Electric Power Online Earnings Rights Asset Support Special Plan" was successfully issued and listed on the Shenzhen Stock Exchange. On August 25, the first green asset-backed securities of the Shanghai Stock Exchange, "Nongyinsui Yingying. Jinfeng Technology Wind Power Charge Revenue Right Green Asset backed Securities" was listed on the Shanghai Stock Exchange. On September 29, " Huifu Huatai Asset Management - Asset Support Special Plan Asset of China Re - resource Abandoned Electronic Products Treatment Fund" was successfully listed in the quotation system of the China Securities Regulatory Commission, becoming the first green circular economy asset securitization project of a central enterprise in the country[4]. According to statistics from Wando, from June 2015 to December 2016, 11 green asset-backed securities were issued, all of which are infrastructure charging rights, with a total amount of more than 10 billion Yuan.

In 2017, the stock of green bonds in China's bond market reached 261 issues, with an issue amount of 2067.80 billion Yuan, an increase of $4.16 \%$ over 2016. However, the scale of green asset securitization did not account for a large proportion of the total issue amount of green bonds, with 10 green ABS issued, accounting for $78.06 \%$ of the total issue amount of green bonds, with a total issue amount of 146.05 billion Yuan, accounting for only $7.06 \%$.

In March 2018, China's first asset-backed securities " CICC - Guicheng Huinong Micro - loan Asset Support Program" earmarked for rural revitalization and poverty alleviation was issued with a letter of no objection from the Shanghai Stock Exchange. In May, Hengan Electric Power's Green Hydropower Asset Support Project was successfully launched in the inter-agency private offering and service system. The product was the first asset securitization project with the characteristics of poverty alleviation and green. In the first half of 2018, 48 "labeled" green bonds were issued in China, with a total size of 52.372 billion Yuan. Green ABS issued a total of 7 in the first half of the year, accounting for $14.58 \%$ of the total number of green bonds. The issue size was 5.512 billion Yuan, accounting for $10.53 \%$ of the total size of green bonds[5]. 


\section{DeVelopment of Green Asset Securitization in} CHINA

\section{A. Lack of Relevant Laws and Regulations on Green Asset Securitization}

At present, the People's Bank of China, China Securities Regulatory Commission and China Banking Regulatory Commission and other departments have issued some relevant rules and regulations, but they have not yet formulated relevant national laws and regulations, and there are problems such as low legislative level and insufficient authority. The relevant policies issued are also lack of pertinence and guidance and far from meeting the needs of market development. At present, only the Securities Regulatory Commission has explicitly carried out the green asset securitization work with reference to the relevant requirements of green corporate bonds, and there is still no special legislation or system to regulate the green asset securitization business. The relevant indicators and participants' obligations and rights of green asset securitization do not match the current relevant laws, regulations and rules.

\section{B. Lack of Professional Talents and Specialized Organizations and Insufficient Promotion Efforts}

With the gradual increase in the promotion of green asset securitization, the innovation of green asset securitization products has accelerated and a large number of new products have been issued and listed. Although green asset securitization is still in its initial stage, its application of related knowledge is complex and huge, and its development requires a large number of professionals to study and popularize. Professional talents do not match the ever-increasing wealth of green asset securitization products. At present, the training of professionals by relevant departments is far from meeting the needs of the development of green asset securitization, especially the shortage of professionals with relevant legal knowledge and technical experience. The lack of professional talents in the industry is not comprehensive and thorough, and some businesses cannot be carried out. At present, there are very few financial institutions that can successfully set up green financial departments in China, but they still need to strengthen the construction of professional teams. The lack of professional talents and specialized organizations is not conducive to the popularization of green asset securitization, resulting in the lack of public awareness of it. It is more likely that the public will gain incorrect knowledge from illegal and unprofessional channels and mislead the public.

\section{Green Asset Securitization Market Supervision System Imperfect}

On the one hand, the green financial information disclosure platform is not sound, the basic asset related information of green asset securitization cannot be disclosed in time, and the information of original stakeholders is difficult to obtain. However, investors in the market demand high transparency of green asset securitization information and require relevant departments to disclose relevant information regularly. Therefore, the current information disclosure platform cannot meet the actual needs of the market. The cross-market and unified information disclosure requirements for green asset securitization have not yet been issued, limiting the effective supervision of the public over the development of green asset securitization. On the other hand, under the pattern of separate supervision, the supervision of green asset securitization between regulators and relevant agencies cannot establish information sharing, and there is a lack of effective and timely communication, resulting in a regulatory gap. The separate supervision system has strengthened the difficulty of the examination, approval and operation process of green asset securitization products, which takes a long time and cannot meet the needs of the market business for the time being.

\section{Suggestions for Promoting the Development of GREen AsSET SECURITIZATION}

\section{A. Improve the Relevant Legal System}

Improve the legislative level of green asset securitization, strengthen the authority of relevant laws, use the force of law to strictly control the green asset securitization market, ensure the effective implementation of relevant systems and promote its healthy development. On the one hand, it supplements the legal provisions lacking in green asset securitization in the Securities Law, or directly designates a series of laws and regulations on green asset securitization, clarifies its definition, standard principles and other contents, determines its legal status, and establishes a unified trading market. On the other hand, strengthening the construction of supporting system for green asset securitization, relevant departments should further improve laws and regulations on natural environment protection and management and clarify the legal responsibilities of those who damage the environment. Improve the intermediary service system of green asset securitization, improve the green financial evaluation institutions, and combine with the local government rating departments to greatly improve the evaluation efficiency of green projects. Research and integrate relevant fiscal and taxation policies, monetary policies, credit policies and industrial policies. For example, various departments can give financial subsidies to key green industrial projects, reduce and exempt relevant taxes and fees, and establish and improve relevant supporting policies for green asset securitization. Finally, while improving the relevant laws and regulations and supporting policies, it is necessary to strengthen the enforcement power of the relevant responsible departments,, have laws to follow and be prosecuted for violating the law, and comprehensively promote the development of green asset securitization.

\section{B. Training Comprehensive Professionals and Strengthening Team Building}

In order to innovate green financial products, explore new green financial development models and enrich the connotation of green finance, relevant government departments and financial institutions must train comprehensive professionals and build professional management teams. Comprehensive professionals not only have the required professional knowledge, but also must establish a moral bottom line, be able to know the law and abide by laws, regulations and professional ethics. Training comprehensive professionals should start with schools. Teachers should not only impart professional knowledge, but also educate students to learn relevant laws, regulations and professional ethics, and consciously abide by laws, regulations and professional ethics. Financial institutions or relevant departments have reached cooperation to formulate 
training plans in advance, make use of existing resources, set up talent training bases and reserve professionals for China's green asset securitization in advance. In order to build a professional management team, financial institutions and relevant departments should regularly organize employees to conduct business study and quality development so as to improve the comprehensive quality of employees in all aspects and further cultivate a highly professional team. Institutions can also hire industry experts, such as environmental protection, new energy and legal fields, to set up a comprehensive database. Relying on the database to carry out industry research and organize bank-wide training to train compound talents in the fields of environmental protection, finance and law to build professional management team. Moreover, we will make full use of all kinds of media and internet platforms to actively promote the concept of green sustainable development and green finance related professional knowledge to create a good social environment for the development of green asset securitization[6].

\section{Strengthening Market Supervision}

With the rapid development of green asset securitization market, its existing problems are also gradually prominent. In order to avoid serious violations in the process of green asset securitization, on the one hand, institutions should adhere to the improvement of the information disclosure system, improve the standardization of information disclosure, and timely disclose the basic asset levels of green asset securitization products. Major types of basic assets should be gradually disclosed in detail, innovative products should be disclosed in detail, and relevant databases should be established to properly preserve relevant information so as to be subject to supervision at any time. The information disclosure system established by the department should cover all issuance projects, ensure the integrity of the project duration, and meet the query and analysis needs of investors and third-party valuation agencies. On the other hand, the financial supervision department should set up an effective two-way information communication and sharing platform in all departments and institutions to timely communicate the handling of violations of laws and regulations. The government, financial institutions and social intermediaries should establish a stable inter-departmental coordination mechanism, make full use of the power of social supervision, and timely understand the implementation of various policies. Improve China's independent third-party certification system, standardize the evaluation of green asset securitization by thirdparty certification bodies, effectively help investors to understand the specific situation of relevant projects more clearly and in detail, and help decision makers make better judgments[7].

\section{CONCLUSION}

Based on the strategy of rural revitalization and the concept of green finance, this paper first defines the concept of green asset securitization, compares it with other asset securitization, analyzes its four characteristics, and summarizes the relevant policies to encourage the development of green asset securitization and the market issuance of green assetbacked securities in China in the past five years by consulting a large number of data, and then discusses the problems faced by the development of green asset securitization. Finally, some suggestions are put forward to promote the development of green asset securitization from the aspects of relevant laws, professionals and market supervision.

\section{REFERENCES}

[1] Liu Zhaoying, Gao Yao, Wu Hui. Green Financial Development Model Based on Asset Securitization [J]. Journal of Agricultural Bank, 2018 (03): 18 - 21.(In Chinese)

[2] Meng Xiaoqian, Guo Youjia and Wang Xiaoqai. Research on the Operation, Development and Path Optimization of Green Asset Securitization [J]. Times Finance, 2018 (09): $203+$ 205.(In Chinese)

[3] Zhu Jin, Li Yongkun. Analysis of financing modes of green industrial asset securitization and intervention modes of financial institutions [J]. Modern Management Science, 2017 (10): 72 - 74.(In Chinese)

[4] Li Bo. Asset Securitization Development Report in the First Half of 2018 [J]. Bonds, 2018 (07): 38 - 42.(In Chinese)

[5] Ji Ming. Discussion on the development of green finance by commercial banks [J]. Finance, 2018 (02): 3 - 10.(In Chinese)

[6] Gao Jiang. The supervisory system of asset securitization market needs to be improved urgently [J]. Chinese financier, 2018 (07): 141.(In Chinese) 